\title{
4 \\ Conjugal Love and Conjugal Family on Trial
}

In 1938 the Chōsen High Court delivered a decision on a divorce case. The wife had sued her husband for a divorce, claiming that he had "gravely insulted" her by keeping a concubine. "Grave insult" (jüdaina bujoku) was one of the legitimate grounds for divorce, according to the Japanese Civil Code. The High Court granted the wife divorce and alimony. To the husband's objection that concubinage was a legitimate custom among Koreans, the judge replied, "Just because some sectors of Korean society commonly practice the evil custom of concubinage does not mean that the above criminal activity of the husband should be condoned." $T$ The decision overturned a decades-long precedent and was celebrated by the Korean newspaper Tonga Ilbo as a significant expansion of women's rights. ${ }^{2}$ In another divorce case in 1943, the High Court again granted a divorce on the grounds of concubinage and explained that the decision was a response to how "the way of marriage" (kon'in no dōgi) was slowly spreading among Koreans. ${ }^{3}$

These High Court statements reflect the vision of legal assimilation then being applied throughout the Japanese Empire during its wartime period. Although the Japanese maintained separate legal spheres in their colonial territories with different degrees of integration with the Japanese home islands, marriage and divorce matters increasingly were subject to assimilation reforms. The status of concubines changed accordingly. Concubines had been allowed to register as such in the household registers (minseki) established in 1909. But in 1915 concubines no longer were allowed to register. When a major reform in the Household-Registration Law (Kosekihō) in 1922 redefined the registry as having a legal effect on all aspects of personal status, including marriage, all unregistered marriages became concubinage. A major reform in the Civil Ordinances in 1922 expanded the categories of 
family matters to be adjudicated under the umbrella of the Japanese Civil Code rather than Korean customs, with marriage and divorce being critical components. ${ }^{4}$ With the 1922 reform, divorce by lawsuit was made possible among Koreans.

Yet the reality of legal assimilation on the ground was further complicated by the fact that even with the expanded application of Japanese laws in Korea, the colonial territory remained a separate legal sphere and the High Court of Korea still had the power to choose when to apply Japanese precedents to Korean cases. If the new Civil Ordinances had been fully implemented in 1922, divorce on the grounds of concubinage would have been possible in Korea, according to the Japanese precedent established in 1918. Instead, citing the prevalence and wide acceptance of concubinage among Koreans, the High Court of Korea declined to grant Korean wives divorce on the grounds of concubinage until the 1938 decision. The shift came only after a transition occurred in the colonial policy in Korea for "forced assimilation" (kominka) by the colonial state, that is, the Government General, following the outbreak of the Second Sino-Japanese War in 1937. The extension of Japanese laws on son-in-law adoption and the Name-Change Policy (Sōshi Kaimei) with the 1939 Civil-Ordinances Reform were further steps toward assimilating the family laws in the colony to those of the Japanese metropole. ${ }^{5}$

The selective application of Japanese divorce laws between 1922 and 1938 created a legal limbo that influenced the meaning of the conjugal relationship, whether as legal marriage or concubinage, in colonial Korea. Affection and companionship emerged in this period as critical components of the conjugal relationship for Koreans. ${ }^{6}$ This process, which I call the "affectivization" of the female spouse, coincided with a penchant for romantic love in public media and popular novels. The continuing condonement of concubinage in Korea, ironically, accelerated the affectivization of the female spouse. It was through the debates over concubinage, expressed mainly in newspaper articles and in the civil courts, that ideas about monogamy and conjugal love were most intricately articulated. Also notable was the shifting role of male spouses in this period, with the new legal obligation of male household heads to support their dependents economically. This strengthening of household-head rights through exclusive economic obligations went hand in hand with the affectivization of the female spouse. Yet the new obligation of husbands did not clash with Korean customs in the way monogamy did, and thus discourses about male spouses were nowhere near as close to the center of public attention as were issues concerning concubinage and wives.

The new ideal of conjugal love worked in conjunction with-rather than being antithetical to-the family-state ideology of the Japanese Empire and the family system that the colonial state sought to implement in Korea. Evidence suggests that ideas about conjugal love were sometimes used by both the colonial courts and the Korean litigants to frame nominally illicit relationships as, in fact, monogamous relationships compatible with the colonial family system. The colonial court, over time, moved from the strict enforcement of marriage registration to a 
looser acknowledgement of common-law marriage, which also assumed affective companionship as its critical component. The qualitative transformation of the conjugal relationship predated the 1938 full assimilation of Korean marriage and divorce law to that of the Japanese metropole, and in this sense "the way of marriage" seems to have spread earlier, at least among some segments of the educated, urban population.

\section{THE PROBLEM OF CONCUBINAGE}

There are ten cases of divorce in the Chōsen kōtō hōin hanketsuroku (Verdicts from the High Court of colonial Korea). ${ }^{7}$ Among the ten, three were direct appeals to have concubinage acknowledged as suitable grounds for divorce. These numbers reflect only those cases that reached the High Court; judging from newspaper reports, the number of cases in the local and appellate courts were much higher. High-profile cases concerning divorce and concubinage frequently appeared in Korean-language newspapers, some of which I analyze here, and are evidence of the great interest among the literate public in the issues of concubinage and monogamy.

Monogamy had become normative in the Japanese metropole only a few decades prior. Concubinage had been rare in Tokugawa Japan, but considered an acceptable way to obtain an heir necessary to continue the family line. ${ }^{8}$ After the Meiji Restoration, and after Western culture became the standard against which a culture's level was judged, monogamy became the marker of civilization and concubinage that of backwardness, as early as the 1870 s. $^{9}$ With the 1872 Penal Code, concubinage in Japan lost legal recognition, although legal recognition of children born out of wedlock (ninchi) provided legal protection for concubines and their children. ${ }^{10}$

Monogamy emerged as one of the key topics of discussion, along with equal rights and women's education in the discussion of women's rights in the People's Rights Movement. ${ }^{11}$ The norm of companionate marriage, recently established in the West, quickly traveled to Japan in the uneven political terrain of the midnineteenth to early twentieth centuries. ${ }^{12}$ Ellen Key's Love and Marriage (English edition, 1911) was translated by the famous Japanese feminist, Hiratsuka Raichō, in 1913 and influenced many subsequent writings that promoted marriage based on love. ${ }^{13}$

That concubinage during the colonial period in Korea was not merely a stagnant remnant from the past has been pointed out by a number of recent studies. The Korean historian Chŏng Chi-yŏng (Jung Ji Young) has suggested that concubinage practiced by New Women in colonial Korea conformed to the modern liberal ideal of conjugal marriage. ${ }^{14}$ In colonial Korea, according to Chŏng, concubinage was an appealing if not ideal option for educated young people as a way to realize the newly circulating ideal of companionate marriage, especially for men 
who were already in arranged marriages. ${ }^{15}$ So Hyŏn-suk has argued that the prevalence of concubinage in the colonial period was in fact a product of social and legal changes during the colonial period that had diminished the stigma attached to concubines and their offspring. ${ }^{16}$ Both studies resist the simple characterization of concubinage as a backward custom suffocating the marriage system in Korea, instead analyzing it as an institution changing under Japanese colonial rule. I seek to highlight the particular changes to concubinage that ensued from a dynamic engagement between cultural discourse and the colonial legal system. Placing the debate over concubinage at the center of my discussion furthermore enables me to disrupt the dichotomy between the wife and the concubine, modern and traditional, and examine the legal transformation of the conjugal relationship at large, which was moving in the direction of the affective conjugal ideal.

The ways in which the affective conjugal ideal in colonial Korea was spread in part through the extension of the Japanese Civil Code challenges us to rethink the political, social, and cultural role of the Japanese family system in the Korean colony. In previous studies on Japan, the affective conjugal ideal was understood to be an antithesis to the Japanese family system (ie-seido), created by the Meiji state by drawing on the Tokugawa family customs of the elite samurai class and codifying them in the form of the Meiji Civil Code (1898). The Japanese state utilized the system to enforce familial hierarchy and to cultivate loyalty and the subordination of individual desires to family and state prerogatives. ${ }^{17}$ Conjugal love, with its assumption of equality in relationships and free choice of partners, thus stood in opposition to this state-decreed concept of the family. In literature such tension often was expressed in the narrative of family drama, where the young protagonist is forced to choose between love (to his or her partner) and obligation (to his or her respective parents). ${ }^{18}$

What I show in this chapter, in contrast, is how the conjugal-family ideal itself was a critical component of the family system that the colonial state was implementing in the Korean colony. The contention over legitimate conjugal relationships that unfolded in the 1920s and the 1930s reveals that a significant part of the legal assimilation of Japanese colonial rule involved mobilizing the emotions and desires of the colonized Koreans. The consequence of Japanese family policy delineated here shows us that the "affective grid of colonial politics" applied not only to the colonizers but also to the recipients of the colonial policy. ${ }^{19}$ The colonial power, in other words, not only shaped the colonized people's sentiments but also informed their attitudes toward colonial policy. This is not to claim that the impact of colonial legal policy on Koreans was uniform across all sectors of society. Some scholars have pointed out that, for example, the influence of Japanese colonial legal policy on Korean family practices was minimal, especially in rural areas. ${ }^{20}$ Even so, I argue that previous scholarship has been too limited in considering the culture of love and romantic relationships that emerged in the 1920 s as something confined to literary and cultural phenomena alienated from the actual 
experience of colonized Koreans. ${ }^{21}$ New ideas about conjugal love in the urban, literate circles of Korea had an inherent relationship with colonial policy at large, and their impact on Korean society was not confined to literary discourses alone. In the legal debates-and novels - of the time we can see that love and the conjugal ideal were critical to the Japanese colonial project of assimilation as mediums through which the Japanese family system was implemented in colonial Korea. In other words, such emotions and desires were often produced and expressed through particular power relations dictated by the colonial state. Neither was the hegemonic language of love and affection limited to use by the New Women and Men-as evidence shows, such ideals were disseminated through the colonial legal system to a wider sector of Korean society, to the extent that common concubines previously considered passive victims of tradition were among the first to actively embrace the ideal of conjugal love.

\section{CONCUBINAGE IN THE CHOSŎN PERIOD}

The distinction between wife and concubine in Korea involved multiple layers of cultural meaning that originated as far back as the Koryŏ-Chosŏn transition period at the turn of the fifteenth century. As part of adopting neo-Confucianism as the official political ideology, the Chosŏn court reformed the polygamous practices of the Koryŏ dynasty along the lines of Confucian family prescriptions and allowed men of its ruling elite yangban class only one wife and one concubine. ${ }^{22}$ Other legislation followed that discriminated between a husband's wife and his concubine and, further, between their respective offspring. Only wives could obtain official honorary titles and have a place in the lineage shrine of the husband's family, and only a wife's children could sit for civil-service examinations. Heightened competition between yangban elite families in the late Chosŏn dynasty led to the consolidation of the patrilineal kin group, which involved further stratification between the offspring of wives and concubines within lineage practices. Children of concubines could not be appointed as jural heirs, that is, heirs to ancestral rites, even when the family did not have other sons. Resentment by the children of concubines against such legal discrimination became a mounting social problem by the late Chosŏn dynasty (the late seventeenth to late nineteenth century) and functioned to continually put the problem of concubinage at the center of public demands for social reform. ${ }^{23}$

The definition of concubines in the Chosŏn dynasty depended more on the status of the women's birth families and the process of relationship formation than on the marital status of the male partner. Concubines of men from the elite yangban class were chosen from the commoner or the slave classes, and the relationships lacked the proper rituals required of formal marriages. ${ }^{24}$ Because the definition and status of a concubine depended on her lower social origins, a concubine could never become her partner's wife even if his wife died. Records from the Chosŏn 
dynasty suggest that a relationship with a concubine could be managed in a variety of ways, from a fleeting affair lasting only for a few years to a lifelong connection. ${ }^{25}$ A concubine could share dwellings with the main wife or live in a separate dwelling; in the latter case she might reside near the main home or in a remote region where the husband regularly visited, such as his government post or his hometown. Single men might acquire a concubine without also having a wife. A widower had the choice to keep a concubine or marry a new wife.

After the onset of Japanese colonial rule, the definition and status of concubinage shifted from a ritual to a legal basis. Instead of a definition based on family status and rituals, the colonial definition of concubinage was based on a lack of registration in the household registers. Therefore, even a common-law wife acquired through proper rituals could legally be considered a concubine if unregistered. ${ }^{26}$ On the other hand, a concubine could always be made a wife by registering her as such, a path that had been denied to concubines in the Chosŏn dynasty. ${ }^{27}$ Furthermore, since the Kabo Reforms in 1894 abolished the customary ban on making the offspring of a concubine a jural heir, a concubine in the colonial period possessed increased power in the relationship, as her son had the potential to become the future head of her partner's household. ${ }^{28}$

However, older definitions of concubinage, together with the lower-class stigma attached to the nomenclature, lingered on into the colonial period. Traces of the old ideas about concubinage can be seen in the legal records. Families would call a wife of a widower who remarried a "concubine," even if she was the legally registered wife, if she fit the typical mold of the traditional kind of concubine: a woman much younger than the husband or from a humble background. ${ }^{29}$ The social shock about New Women becoming concubines comes as much from the stigma of low class attached to the nomenclature as the adulterous nature of the relationship.

\section{CONCUBINAGE AS MARITAL OFFENSE}

The normative form of the conjugal relationship is difficult to ascertain in the context of colonial Korea, because there was a discrepancy between legal codes and social practices. First of all, there was the chronic problem of unregistered marriages. After the first implementation of household registers in 1909, the governor general repeatedly declared the principle that registration was the only means through which personal status was officially recognized (todokede shugi), yet many Koreans put off registering a personal change of status, such as birth and marriage. Therefore, many conjugal relationships that Koreans considered legitimate were illegitimate in the eyes of the law. A government inquiry from the 1920 s shows the discrepancy between the official vision and the local understanding of legitimate marriage: the local official referred to an unregistered spouse as a "wife," while the bureaucrat from the Office of the Governor General consistently referred to her as a "concubine," emphasizing her unregistered status. ${ }^{30}$ One Tonga Ilbo article as late 
as 1934 surmised that all Korean couples delayed registering their marriages and, therefore, experienced a common-law stage at some point. ${ }^{31}$

Another problem was the ambivalent stance of the governor general on the issue of concubinage. While the colonial state officially backed the principle of monogamy, the colonial courts protected concubinage in legal decisions. Although excluded from household registration since 1915, concubines received de facto protection of their status in the civil courts. Until 1922 a concubine, rather than her partner's legal wife, had parental rights over her own children. Often concubines were treated just like wives, especially if there were no living wife with the partner. ${ }^{32}$ If she was registered as a concubine before the 1915 ban, she was burdened with the same legal constraints as a wife, such as spousal cohabitation. ${ }^{33}$ Even after the 1922 revision of the Civil Ordinances subjected marriage and divorce matters in Korea to the Japanese Civil Code, concubinage still was protected as a legitimate Korean custom in the colonial civil courts. ${ }^{34}$ Citing the prevalence of concubinage among Koreans, the colonial court denied Korean wives the right to divorce on the grounds of concubinage. Such decisions blatantly ignored legal precedents established in the Japanese metropole. Japan had made concubinage a legitimate ground for divorce in 1918, with the Japanese Supreme Court (Daishin'in) ruling that concubinage amounted to a "grave insult" to the wife..$^{35}$ In other words, even after the official assimilation of divorce laws in 1922, Korean wives were not fully granted the same divorce rights as their Japanese counterparts. Such decisions illustrated for the Korean wives the legal consequences of living in the colony, where the country's supposed cultural backwardness was in fact arbitrated by the colonial state. ${ }^{36}$

Indeed, concubinage in the 1920 seemed to be far from declining. One writer claimed that "more than half of middle-class Korean families keep concubines" and that "some even keep three or four [concubines]," arguing for a national movement to abolish the custom..$^{37}$ Reports of concubinage gone awry frequently appeared in the newspapers: women committed suicide to escape the fate of becoming concubines; men killed themselves from the economic pressures of keeping many concubines. In an opinion piece, one writer suggested that Koreans could solve the school-shortage issue by persuading the rich to spend money on building schools instead of on luxury items and concubines. ${ }^{38}$ Reports on possible taxation for keeping concubines also adorned the papers. ${ }^{39}$ Scandalous accounts that emerged in the mid-1920s about the New Women, those paragons of globalized modernity who had chosen the status of concubines, seemed to further darken the prospect for Koreans overcoming this backward custom.

Despite being condemned as backward, concubinage seems to have been bolstered by the growing importance of love emerging in discourses at that time..$^{40}$ In opposition to the criticism that concubinage was an old, backward custom, others began to redefine it as a new and modern relationship based on love. Even in the writings that condemned concubinage as a serious social problem, the authenticity 
and inherent goodness of the romantic relationship undergirding such relationships were seldom questioned. Many of the newspaper articles that were critical of romantic relationships nonetheless implied that they were based not only on sexual attraction but also emotional and intellectual compatibility by mentioning the comparable levels of education of the two parties. While "moral depravity" in relationships with concubines was still condemned, so were the old customs that confined young people in loveless marriages. While men surely should be condemned for deserting their wives, they also were to be pitied for being trapped in marriages that had been arranged by parents when they were barely teenagers. ${ }^{41}$ And while New Women were criticized for luring married men, blame also was assigned to the wives who failed to educate themselves to become suitable companions to their husbands. ${ }^{42}$ Both concubines and their partners portrayed themselves not as perpetrators but as victims of old evil customs. Some intellectuals even asserted that concubines should be identified with a new name, the "second wife" (chei pu'in), rather than the stigmatized word "concubine" (chöp).43 Regardless of the morality of their status, they were victims, these intellectuals claimed, of the backward custom of early marriage, which tied men to unwanted marriages before they had a chance to meet companionate mates.

In other words, in a family culture where arranged marriages still prevailed, concubinage was embraced as an alternative institution that enabled young people to realize the new conjugal ideal in a romantic relationship. ${ }^{44}$ Chŏng Chi-yŏng posits that perhaps the reason why some New Women became concubines was because concubinage offered them the unique (and rare) path to the affective conjugal-family ideal of the "simple home" (tanchol'han kajöng). ${ }^{45}$ Far from being ill-informed victims, they entered the extramarital relationship with their eyes wide open; it might have been a better option than what awaited them in a regular marriage: domineering in-laws, absent husbands, burdens of housework and child rearing. Chŏng suggests that, given the common Korean family structure of the stem family, where the married couple cohabited with the parents-in-law, concubinage perhaps provided a respite from the conventional arrangement of marriage. ${ }^{46}$ For these women, then, a companionate relationship trumped the legal securities of marriage as the guiding principle in charting their lives.

Yet the hegemonic language of love also increasingly was used to support the monogamous relationship in legal marriages. In the 1920 s women in the colonial civil courts began using the language of conjugal love to argue that Korean wives should be allowed to divorce when the marriage lacked an exclusive loving relationship, namely, when their husbands kept concubines. Records of civil litigations show us how colonized Koreans maneuvered within the colonial legal system to articulate or legitimize competing visions of conjugal relationships.

Contemporary newspaper reports about wives who alleged concubinage as grounds for divorce would have served as sources of information for literate women considering their legal options. Divorce cases were the stock of sensational 
journalism at the time and newspaper readers were treated to all kinds of details of the failed marriages. All too often, the failed marriage involved concubines. Divorce cases mentioning concubinage as the major source of marital discord appear as early as 1921, although the newspapers did not always report the verdicts. ${ }^{47}$ In 1928 alone the newspaper Tonga Ilbo reported two cases of wives suing over their husbands' concubinage. In the first case, the wife sued for a divorce because, even after she married her husband, he continued to live with his concubine and refused to cohabit with or support her. The article reporting the complaint was titled “Ch’ukch’ŏp namp'yŏn silso: Sinyŏja ŭi ihon sosong [Doesn't want husband who keeps a concubine: A New Woman's divorce suit]." In the second article the wife implemented the unique strategy of suing her millionaire husband, Kim Yŏn-yŏng, for cohabitation and the expulsion of two concubines instead of divorce. She won the case. The judges in the Keijo Local Court affirmed that "concubinage is not only humanely unreasonable but also the main cause destroying the peace of homes, which should be the foundation of the state." While the title of the article- "Pŏmnyul sang ŭrodo ch'ukchŏp ŭn pulga [Concubinage is even legally impossible]"-clearly overstated the decision rendered by the court, a legal advice column in 1932 nonetheless recommended that a wife should sue for divorce on account of a husband's relationship with a concubine. ${ }^{48}$

In 1928, the same year in which Tonga Ilbo reported on two lawsuits over concubinage in the lower courts, Yi Myŏng-rye appealed the lower-court ruling in her divorce suit on the grounds of her husband's concubinage. Although she eventually failed, the case shows how the affective relationship as a primary foundation of legitimate conjugal ties began to emerge as a strong rhetorical tool in legal disputes. This case had all the common trappings of a 1920s divorce case: mother and daughter-in-law conflict; husband's battery of the wife; wife's escape to her natal home; and, in addition, the keeping of a concubine by the husband. The details of the case probably took cues from what was stipulated as grounds for divorce in the Japanese Civil Code, article 813, which had been partially extended to Korea in 1922. ${ }^{49}$ Yi argued that the fact that her husband, Pak, kept a concubine and forbade Yi to return to the house amounted to "malicious abandonment" and a "grave insult," both stipulated as legitimate grounds for divorce in article 813. Pak claimed that it was his wife who provided reasons for the marital discord, and, when Yi ran away from the house, he had no other recourse than to take in a concubine to care for his mother and look after household tasks, such as cooking and cleaning. The local and appellate courts (fukushin hoin) sided with the husband and denied Yi the divorce. "If this is why the defendant is cohabiting with the concubine," the appellate court's statement concluded, "this does not amount to malicious abandonment or grave insult." 50

The appellate court did not break any new ground here; it was merely following the precedents in the colonial Korean courts. At that point no Korean woman had had any success in obtaining divorce on grounds of concubinage. Nonetheless, 
Yi ventured to appeal to the High Court probably because she, or her lawyer, thought that, with the 1922 reform in Civil Ordinances, the 1918 Japanese Supreme Court decision that declared concubinage a marital offense in Japan should also be extended to Korea. ${ }^{51}$ She indeed cited the 1918 Japanese decision that had ruled that malicious abandonment and grievous insult are not affected by whether or not the other party provided a cause or if concubinage resulted from necessity. ${ }^{52}$

To demonstrate that she was due the protection of monogamy, Yi Myŏng-rye seems to have believed that she needed to demonstrate her faith in exclusive emotional ties as the legitimizing grounds for a marital relationship. In her appeal to the High Court, to emphasize that the principle of monogamy also applied to marriages in Korea, Yi declared, "Marriage can be sustained only with love [ai] between opposite sexes." She continued, "The love that is necessary for the sustenance of marriage is a holy one and must be singular and exclusive." She went on to criticize the appellate court decision for being discriminatory to women in the colony. To the court's reasoning that the husband's battery and concubinage did not amount to grievous insult because she, the wife, had provided the basis for the marital discord, Yi responded, "[Such a decision] would lead to producing a malicious custom even worse than the current malicious custom of concubinage. . . Neither the [Japanese] Civil Code nor Korean custom today discriminate between men and women to such a degree. Rather, they condemn concubinage regardless of the reason." 53

Despite all her efforts, Yi was unsuccessful and the High Court again turned down her appeal for divorce. The judge's reasoning, in short, was that Korea was different from Japan: concubinage was still too common in Korea; therefore, Korean wives should not feel so insulted as to impede the normal continuation of the marriage in such circumstances. The exact wording of the High Court decision decreed the following:

The evil custom [heifü] of concubinage is still prevalent in certain strata of Korean society, and the general public has an accepting attitude toward the practice and does not consider it a grave wrongdoing. If such is the circumstance among Koreans, it is difficult to say that just concubinage alone constitutes a grave enough insult to impede cohabitation with the wife, in other words, grounds for divorce from the wife. ${ }^{54}$

To assert concubinage as grounds for divorce, Korean wives first would have to refute what the colonial court perceived as a prevalent Korean custom and then appeal to the established precedent in the Japanese metropole. How to wage such a struggle successfully was a tricky question, as the High Court's perception was not necessarily based on a quantifiable observation. ${ }^{55}$ Legitimizing a separation of legal spheres between Korea and Japan on the basis of different customs seems barely supportable when we realize how closely and quickly some Koreans, such as Yi, were embracing the legal developments in the Japanese metropole. It also shows how the maintenance of such separate legal spheres may have motivated women 
from the colony, like Yi, to support expedient assimilation of civil laws in Korea. Yi Myŏng-rye expressed her belief not only in her rights as a wife to a monogamous relationship with her spouse but also in her rights to legal treatment equal to her metropolitan counterparts.

What is notable in this case is Yi Myŏng-rye's choice to foreground the language of love and affection in her argument despite the absence of any legal precedent for the effectiveness of such a strategy. The most common and successful reason for divorce was battery, either of the wife or the wife's parents. ${ }^{56}$ Another frequent reason was "malicious abandonment" of one spouse of the other..$^{57}$ Yis strategy may well have been based on her perception of the larger trends occurring in the legal arena at the time, but her argument was possibly inspired also by the popular discourse about conjugal love, which often called for exclusive love in marriage..$^{58}$ In August 14, 1928, Tonga Ilbo printed an opinion piece, "Ihon su ŭi kyŏkchŭng, sinjunghi koryŏ hal munje [Explosion of divorce rate, a problem of careful consideration]." The article noted that divorce itself was not new in Korea, but "what is notable is the divorce that derives from the transformation of thoughts [sasang pyŏnchön], that is, the man abandoning a wife after he gained [modern] knowledge, and the wife abandoning a husband after she became progressive." The article also noted that many divorces resulted from a "free love-relationship" (chayu yŏne). The writer then went on to argue that "the true meaning of married life is for the husband and wife to love each other and to pursue the happiness of home," and therefore people should distinguish this true domestic happiness from the "simplistic hedonism" (tansunhan k'waerak ju'üi) and "fleeting feelings" that are the source of a "temporary love-relationship."

In 1933 Tonga Ilbo ran a serialized article, "Segye kakkuk ŭi rihon pŏpche wa chosŏn rihonpŏp ŭi kwagŏ hyŏnjae kŭp changrae [Divorce laws in the world and the past, present, and future of the divorce law in Korea]," that argued for reforms to make it easier for Koreans to divorce. The writer argued that the difficulty of securing a divorce accounted for the increased instances of familial disputes and also the particular problem of female crimes in Korea that involved high rates of husband homicide and infanticide. In the eighteenth installment, the writer cried, "Why should a wife have the obligation to endure when her husband seeks the pleasure of concubinage! Those women who become concubines while fully knowing that the man has a legal wife! Know that you lead the men to concubinage and that you worsen the social system!" The last installment noted that "marriage without love is a constant rape." ${ }^{59} \mathrm{In} 1935$ the author of another opinion piece questioned whether "a marriage should be maintained if the couple lacks affection [aejŏng]."

These newspaper articles show how the growing discourse about conjugal love was not only transforming the understanding of marriage but also aggressively undermining the legitimacy of concubinage. Even articles that excused particular extramarital relations when the marriage was loveless still believed that the 
goal was to move toward companionate marriages that would make concubinage unnecessary. Such statements directly challenged the notion, expressed by the High Court judges in Yi's divorce lawsuit in 1928, that Koreans widely accepted concubinage as a legitimate custom. With the emerging popularity of love and the love relationship throughout the 1920s and the 1930s, the dominant discourse at least among the literate urban population seems to have privileged the alignment of love and marriage. Ironically, the demand for expanded divorce rights was one of the consequences of increased expectations of love and affection in marriage. By 1938, the year in which the High Court first granted a divorce to a Korean wife on the grounds of her husband's concubinage, very detailed legal knowledge about divorce and the unique challenges Korean women faced was made available through a popular novel serialized in a Korean newspaper. In this novel, Millim (The jungle), by Kim Mal-bong, the wife, Cha-kyŏng, decides to sue her husband for a divorce after she finds out about his concubine and their son. Her lawyer recommends, however, that she pursue divorce through agreement rather than a lawsuit, saying, "Since concubinage is acknowledged to a certain extent in Korea, victory would not easily come to the plaintiff." To this reasoning, Cha-kyŏng retorts, "When the husband gravely insults the wife, isn't this the biggest ground for a divorce?" ${ }^{61}$ Cha-kyŏng's statement is very telling, revealing as it does what the contemporary author imagined was possible for an educated woman to know at that time about divorce lawsuits, particularly about the charge of concubinage as a marital offense.

\section{COMPANIONSHIP AND COMMON-LAW MARRIAGE}

Newspaper reports and popular fiction reveal that the emerging discourse of love increasingly came to define legitimate conjugal relationships among the urban middle class in the 1920 s and the 1930 s in Korea. Moreover, some Korean women marshaled the discourse of conjugal love in their attempts to expand divorce rights during the legal limbo of colonial rule regarding concubinage between 1922 and 1938. In this section I analyze a case where the discourse of conjugal companionship was mobilized conversely to legitimize a relationship that was itself on the margin of legality. This case highlights how the emotional component of a conjugal relationship emerged as a central and defining element in this period, to the extent that it overshadowed other elements that had thus far defined legitimate marital relations. In this particular case in 1933, a concubine claimed the status of a wife, and the High Court concurred, stating that her kind of concubinage could be acknowledged as a common-law marriage. The judgment rested on her provision of emotional companionship.

In the case the concubine Yi Sun-gyŏng went to court to claim a piece of property promised to her by her late partner. In a letter (written in 1932) appended to the land title, the man had promised to give her full rights to the land and building 
"if she continued living with him until 1937." As fortune would have it, he died soon after he wrote that letter and well before the agreed time of cohabitation was up. His son and heir refused to relinquish the property to Yi, claiming that she was not eligible to receive the land because she did not fulfill her contract. In addition, the son argued, the contract involved maintaining a concubinage relationship, which was against "public order and good customs."

The outcome of the litigation hinged on the definition of the concubine's relationship to her partner. Was it an illicit and fleeting relationship or was it a lasting relationship, more akin to that of marriage? The success of the concubine's case hinged on her ability to prove that the relationship was a familial one. Her argument reveals the subtle but important shift that had occurred in the definition of familial relationship, from legal and ritualistic to affective. The concubine Yi proceeded to argue that the land was promised to her not as a wage but as a provision for her livelihood and for the child she was carrying in her womb. To regard such a stable and exclusive relationship as a simple liaison, she argued, would actually contradict "our moral convictions" (ware no dötokuteki na shinnen). She also pointed out that her late companion did not have a (living) proper wife, and thus her relationship was more like an "engagement" (kon'in yoyaku), eligible for legal protection.

Engagement was protected as a kind of common-law marriage under the Japanese Civil Code, extended with great publicity to the Korean colony in $1923 .{ }^{62}$ The measure was meant to protect unregistered marriages to ameliorate public reaction to the 1922 Civil-Ordinances Reform, in which the governor general had recognized only registered marriages as legal (hōritsukon shugi). The provision also could be used by wives of unregistered marriages when their husbands tried to "divorce" them without due support. In such cases the wives could sue for compensation on the basis of the husband not completing the promise of marriage. Notably, "engagement" referred not to all instances of unregistered cohabitation but only to those in the process of becoming registered marriages. ${ }^{63}$ Such engagements could be considered full-fledged marriages if they featured a public wedding ceremony, cohabitation, and public representation of the marriage: all that was lacking was the formality of a legal registration. According to a 1935 local court decision, for a cohabitation to be acknowledged as a "common-law marriage," one had to have undergone at least part of the traditional wedding rites of nap'ye (exchange of wedding gifts) and chŏn'an (wedding ceremony). ${ }^{64}$

Yi Sun-gyŏng seems to have lacked the wedding ritual prerequisite; in its place she listed myriad facets of her relationship to depict that she and her partner had had a lasting relationship, like a marriage. Yi pointed out several things that she thought proved that her relationship with the deceased had been an enduring one: she was formally introduced to him by a go-between, and, after entering his house, she prepared his clothing and food. But the central feature of this "marital relationship" that she emphasized was her affective companionship to her partner. 
Considering the age of the late husband when he entered the relationship (sixty), she claimed, he did not enter into it simply to satiate his sex drive but to have a good "companion" (hanryo) in his lonely old age. Yi noted more than once that she was chosen to "provide companionship to [the husband] in old age" and also to "console [him] in old age." She also cited an old Korean saying that "one evil wife is better than ten filial sons."

Yi's choice to present herself as the pseudowife was successful. The decision of the judges to approve her claim stipulated the following:

A husband-concubine relationship [like the one cited] is just like the husband-wife relationship in that they are tied for life. It is not the same as pursuing transient pleasure in invariably seeking concubines or courtesans. One cannot generally dismiss it as being harmful to public order and good customs. ${ }^{65}$

The High Court was in fact making a new distinction in Korean concubinage between a transient and fleeting relationship versus a more lasting one, where "one man and one woman openly live together, having promised to live together for all their lives [shūsei no kyōdō seikatsu wo yaku shite kōzen dōkyo suru]. In light of the status of concubinage during the Chosŏn dynasty, this distinction is clearly artificial. The judges went on to make sure that their decision did not amount to a categorical sanction of concubinage. They noted that, while the relationship was definitely not marriage ( $f \bar{u} f u$ kankei), it was still a legitimate one, akin to a common-law marriage (jijitsujō no füfu).

The High Court acknowledged Yi Sun-gyŏng's familial status not by acknowledging her claim that her relationship was an "engagement" but by introducing a new concept of "common-law marriage" into case history. Nevertheless, the ground on which both Yi Sun-gyŏng claimed legitimacy and the High Court judges rescued the relationship from the category of concubinage is similar. The High Court seems to have been preparing the way for applying the common-law marriage recognition then prevailing in the Japanese Civil Code into Korea, which did occur the following year. The categorical treatment of all forms of unregistered cohabitation as concubinage was being modified, and, critically, the factor that most influenced this redefinition was emotional companionship.

The emergence of emotional companionship as the defining element of a legitimate conjugal relationship was a new phenomenon in the legal scene of this period. The conjugal love that previously had been argued by wives and concubines in their cases did not have the same quality of feeling as the companionship claimed in this case, which definitely lacked a tone of romantic love. Nonetheless, all invoked an emotional element in representing their relationships, which was unprecedented in the prior legal discourse defining legitimate conjugal relationships. What was manifest, especially in the 1933 case, was how an emotional element emerged as the defining factor to tip the scale for a relationship on the margin toward legitimacy. The outcome shows that the ideal of companionate marriage that had emerged in 
the cultural sphere had made its way into the legal discourse to redefine the conjugal relationship. Such cases show that culture and law were not separate but porous spheres that shaped and bled into each other.

Although companionate conjugal love vied with legality in legitimizing conjugality, it did not subvert the marriage system in any way. If anything, the ideal of conjugal love strengthened the husband's exclusive economic rights within the family (especially with regard to property). To gain ownership of the land promised to her, Yi emphatically redefined the promise of the land not as a wage but as a form of economic support. The concept presumed the wife a dependent of the husband, the sole economic provider of a family. Such a redefinition of familial relationships, according to the sociologist Viviana Rotman Zelizer, was also central to the Victorian ideal of the domestic sphere, which had been built on the assumption that economic transactions were antithetical to the definition of family ${ }^{66}$ Zelizer thus reveals how the belief in separate spheres itself, which claims contradictions and separation between the economic and the affective, hides and nullifies the economic value of service and labor conducted within domestic relationships. What we see in Yi Sun-gyŏng's case is how the equation can work in the opposite direction; by denying the economic value of her domestic and intimate work, the concubine earned recognition of her familial status.

This 1933 case over the familial (or spousal) status of the concubine is in striking contrast to a case from the 1910s, where the concubine claimed independent economic rights as customary and as a marker of concubine status. ${ }^{67}$ As the concubine of the late Han Che-uk, Yi Pogwanghwa ran a successful bar-restaurant (chumak) and accumulated great wealth. The problem arose when, after forty years of cohabitation, her partner died. Upon his death, Han's son, Han Kyu-yong, claimed all of the couple's property. When Han sold off 400 majigi of the land, Yi sued to reclaim it. Yi argued that the land was her separate property. "Separate property" was a Japanese Civil Code term for property owned by a wife or an adopted sonin-law (muko yōshi). The term was used to protect a designated property from the household head. While the household head retained management rights over the property, the wife of the adoptee could reclaim the property in case of a divorce or the severance of adoption ties (payang). Thus, the assumption was that a household head held exclusive ownership of a household's property unless it was specially designated as "separate."

Yi argued that, since it was her business, the money she earned from it was hers and so was the land that she had bought with that money. To support her case, she provided two witnesses who testified that they had indeed sold the land to her. The defendants did not deny that it was Yi who had bought the land, but they argued that she merely had been acting on behalf of her husband, who had been sick for many years. They had many witnesses testify that Han Che-uk had, indeed, been ill for many years and thus incapable of handling the legal transactions of business. From the local to the High Court, all the courts acknowledged the defendants' 
argument. The High Court stated that "it was rare for Korean women to have a separate property [tokuyū zaisan] between 1898 and 1902." Since it was assumed that "separate property" was a rare designation in Korea, the burden fell on Yi to prove otherwise. Ultimately, the fact that Han was sick and probably needed a proxy to carry out his legal transactions tipped the scale against her. Ironically, for the reason that her husband was too weak to carry out his own business, Yi Pogwanghwa was denied all ownership of the property.

A few years later Yi came back before the courts with another case. In the second set of lawsuits, which came to the High Court on February 16, 1917, Yi was once again entangled in a dispute over the ownership of a piece of land. The defendants, headed by Han Kyu-yong, had won a case at the appellate court by arguing that all of the couple's wealth was generated from the initial capital provided by Han Che-uk to Yi's business. Therefore, the land belonged solely to Han Che-uk, which, in turn, made Han Kyu-yong the sole legitimate heir. In an effort to tarnish Yis reputation, Han Kyu-yong and the other defendants provided seedy details of Yi's life. Before meeting Han Che-uk, she had been married to three other men, and before coming to live with Han, she had been poor and working as a laborer in an oil factory.

In response, Yi argued that it was Korean custom for a concubine to keep the profits from her business as separate property. After examining the evidence, the High Court concluded that Yi's contribution to the business alone made her eligible to become the owner of the land.

The judge stated,

In Korea, when a wife or a concubine cohabits with the husband, any nondesignated [i.e., separate] property should be presumed to be the husband's. But this is only a presumption, [reserved] only [for cases] when the ownership is unclear. When a wife or concubine, while cohabiting with the husband, purchases a property with the profit earned from her own business, she should be given ownership of this property. The previous decision [of the High Court, referring to the case discussed earlier] states only that it is rare for women in Korea between 1898 and 1902 to have separate property; it does not deny [the possibility] for a wife or concubine to have separate property. ${ }^{68}$

The fact that Han Che-uk was sick and unable to contribute to the business now became the basis for legitimizing Yis ownership of the property and wealth. The High Court also dismissed the appeals court's argument that cohabiting with her husband automatically gave the husband ownership of Yis profits and wealth. That is, cohabitation did not automatically rule out the possibility of separate property.

In these two cases, Yi Pogwanghwa challenged the definition of concubine that the colonial state and the plaintiffs were trying to impose on her and proactively redefined her own status as a concubine. She resisted the plaintiffs' strategy of using her status as a concubine to slight her moral character. And even though the colonial court tried to suppress her identity as a concubine and treat her as a wife, 
Yi reclaimed the meaning of concubinage and embraced her ambiguous position in the family. Although her claim over the property was not granted through validation of her claims to the special customary rights of a concubine, the High Court judges clearly seem to have acknowledged Yi's contribution to the accumulation of property. By ignoring, or bypassing, Yi's claim to the special customary rights of a concubine and treating her rather as a wife with separate property rights, the High Court ended up serving two objectives at once: it delivered justice (by acknowledging rights to what it saw as a rightful owner of the property), and it successfully ignored a backward custom that the colonial government was trying to phase out. Yet what eventually happened was a strengthening of household-head rights, since the concept of separate property could exist only in the context of the monopoly rights of the household head over household property.

In light of the 1933 case, the proactive voice for independent economic rights in the 1917 case is striking. The love and companionship cited in the former presumed economic dependence on the male partner (or husband), thus aligning with the colonial household system more than challenging it. A household system where economic rights were ideally concentrated in the hands of the household head required that other members of the household lack economic rights. One perverse consequence was that a wife's gainful employment (against the husband's will) could be used against her in divorce lawsuits. In a 1931 divorce case, the husband cited the wife's gainful employment outside of the home as evidence of her intention to abandon him. The wife, on the other hand, forcefully defended her employment as a necessary last resort, since her husband had evicted her from their home. ${ }^{69}$ The wife eventually won the case and succeeded in obtaining alimony.

Exclusive economic rights did not always work in favor of the husband, however, as they also meant that the husband household head had the obligation to financially support family members. Wives could, and did, utilize this legal tenet to their advantage, citing their economic incompetence to sue their estranged or ex-husbands for economic support. ${ }^{70}$ Behind the growing attraction of companionate marriage were the harsh socioeconomic conditions of colonial Korea. It was not only cultural expectations that kept women from employment; the Korean economy provided little opportunities for women to achieve economic independence through employment. Although there exists only limited data about the rate and conditions of Korean employment in this era, we can still deduce some conclusions about the prospects for economic independence for women in colonial Korea.

According to a Tonga Ilbo report describing how well the Keijō Job Agency (Kyŏngsŏng Chigŏp Sogaeso) did in the month of March 1929, the largest market for Korean female workers in Kyŏngsŏng (Japanese: Keijō, i.e., Seoul) was as domestic labor for Japanese households: omani, who worked as nannies or housekeepers. ${ }^{11}$ Of successful female employment seekers, 119 out of 121 were employed in such a capacity. These were the fortunate few who found employment, as 
opposed to the 343 women who were not successful. The situation for male employment seekers was even more bleak: only 74 out of 298 were successful in finding work. ${ }^{72}$ Some people criticized unemployed women as "lazy free-riders" (nolgo mŏngnŭn saram) and blamed the "family system" (kajŏng chedo) for this phenomenon. ${ }^{73}$ Articles from the journal Sin Yǒsŏng also affirm that educated women as well had limited career options. A statistical chart from the journal shows that while some became teachers, the majority failed to move onto gainful employment. ${ }^{74}$ Until 1925 Korea lacked tertiary-level schooling for women, and any woman who wanted to continue education after secondary school had to travel abroad to Japan or other foreign countries. An accompanying article in the journal lists letters from students who lamented their postgraduation prospects; many wanted to continue education but lacked adequate funds. Most students complained about the pressure to marry they were receiving from their parents. Another article listed messages of encouragement from school principals; however, their exhortations to young women to continue learning and lead an enlightened life rang hollow in light of the desperation expressed by some of the female students. ${ }^{75}$

With limited prospects for economic independence, the choices for most women were restricted to finding a suitable spouse. Yet even these limited aspirations hit an impasse in the socioeconomic conditions of colonial Korean society. Its underlying economic structure, in addition to the post-World War I economic downturn, allowed for few male white-collar workers who could function as breadwinners for the idealized home. Also, the old custom of early marriage meant that there were only minuscule numbers of eligible bachelors by the time educated women were looking for partners. In such predicaments concubinage may have emerged as a viable option for educated women to acquire a compatible male partner. Behind the prominent and tenacious practice of concubinage existed the intricate workings of the colonial legal system, where women were disciplined into the household system as emotional companions and economic dependents.

The trend toward emphasizing emotional companionship in a conjugal relationship easily transitioned into an expedient wartime emphasis on conjugal ties throughout the Japanese Empire. As war continued after 1931, the ideal of "good wife, wise mother" (ryōsai kenbo) took on added importance as the state tried to strengthen women's ideological role on the home front. ${ }^{76}$ In addition, conjugal ties as expressed through closer sexual relationships also were emphasized to buttress the state's pronatalist policy. ${ }^{77}$ One could argue that the affective conjugal ideal that captured the minds of the educated, urban Koreans during the late 1920s and early 1930 s provided a convenient tool for mobilizing these Koreans to support the wartime family ideal of the 1940 s. $^{78}$ The conjugal-family ideal functioned as a convenient mode of familial relationship that encompassed both Korean desires for family-customs reform and the colonial state's desire for family-law assimilation. The "age of love" was in fact a palatable facade of the age of assimilation. 


\section{CONCLUSION}

Through the lens of the legal discourse surrounding concubinage and monogamy, I have examined how the language of companionate love influenced a redefinition of legitimate conjugal relationships in the 1920 and 1930s. The hegemonic power of affective discourse in legal and cultural definitions of conjugal relationships, I argue, was a crucial component in the implementation of the colonial household system and played an important role in mobilizing the colonized population toward the successful implementation of legal assimilation and social reform. The ways in which the ideal of conjugal love facilitated legal assimilation in colonial Korea thus challenges the existing understanding of the conjugal-family ideal in colonial Korea, as well as in the Japanese Empire as a whole. While many have understood the conjugal family, or home (katei), to be antithetical to the Japanese family system, I argue, rather, that in the context of colonial Korea, the desire to realize the conjugal-family ideal was readily mobilized to support the transplantation of the family system then current in the Japanese metropole to the Korean colony through assimilation of its family laws. Some Koreans, particularly those in urban areas, accepted the expansion of the Japanese Civil Code to Korea as a useful means to reform family customs that they themselves had come to believe were backward and undesirable, such as early marriage and concubinage. Legal assimilation in family matters was one of the few means possible for Koreans to break out of the discriminatory separate legal spheres during colonial rule. The increasing aspiration among some Koreans to enjoy the conjugal ideal appears to have generated colonial consent for assimilationist measures promoted by the Japanese authorities.

In the process of the assimilation of family laws in colonial Korea, another significant process was taking place, namely, the "affectivization" of the female spouse. The more the ideal of the conjugal family gained ground in the cultural discourse, the more emphasized was the role of the affective companionship of the female spouse in the legal discourse. This had a somewhat perverse effect, as we have seen, for as concubines became more like wives and thus part of this affectivization process, they lost independent economic rights. 